At-Turats

Jurnal Pemikiran Pendidikan Islam

journal homepage: http://jurnaliainpontianak.or.id/index.php/atturats

\title{
THE IMPORTANCE OF ENGLISH LANGUAGE IN FACING ASEAN ECONOMIC COMMUNITY (AEC)
}

\author{
Nanik Shobikah \\ Teacher Training and Education Faculty \\ English Education Study Program \\ Universitas Nahdlatul Ulama (UNU) West Kalimantan \\ Email : nanikshobikah2013@gmail.com
}

\begin{abstract}
A B S T R A K
Masyarakat Ekonomi ASEAN (MEA) harus dihadapi oleh Indonesia segera. Diperlukan berbagai persiapan untuk siap di pasar bebas masyarakat ASEAN. Satu hal yang sangat penting dalam kesuksesan MEA ini adalah penguasaan bahasa Inggris. Perkembangan terkini yang terkait dengan identitas bahasa kerja di negara ASEAN dikondisikan bahwa penggunaan bahasa Inggris digunakan sebagai bahasa lingua franca. Lingua franca adalah adalah bahasa yang digunakan untuk berkomunikasi antar orang-orang yang berasal dari berbagai latar belakang bahasa yang berbeda. Lingua Franca merupakan bahasa pengantar atau bahasa pergaulan agar masing-masing pihak yang berbeda bahasa sama-sama mengerti dengan apa yang disampaikan.Peran pendidikan tinggi terutama dalam pendidikan Bahasa Inggris sangat penting dan dibutuhkan oleh masyarakat untuk berkomunikasi secara aktif dengan bahasa Inggris, baik tertulis maupun lisan dalam komunikasi resmi serta berkomunikasi dengan orang lain secara regional dan internasional mengenai kebutuhan dalam kehidupan mereka. Persiapan AEC dalam menghadapi salah satunya dapat dicirikan dengan kesiapan dalam menguasai bahasa Inggris sebagai sarana komunikasi global
\end{abstract}

Keywords: English Language, ASEAN Economic Community

\section{INTRODUCTION}

ASEAN (Association of South East Asian Nations) is the organization of the nations of Southeast Asia. It is established in August 8, 1967 in Bangkok through the signing of the ASEAN Declaration (Bangkok Declaration) by five founder countries, namely Indonesia, Malaysia, Philippines, Singapore, and Thailand. ASEAN evolved into an influential regional community that now includes 10 member

\footnotetext{
${ }^{1}$ Syafrina Fauziah Rashor. 2013. Bahasa Asing

Penunjang Keberhasilan AEC 2015. Jakarta.
}

countries, namely Brunei Darussalam (1984), Vietnam (1995), Laos (1997), Myanmar (1997), and Cambodia (1999). As for Timor Leste is still in the process of becoming a member. ${ }^{1}$

ASEAN is the gateway to get to the global economy where industrial and business activities in the ASEAN region. It is the key. It means that it is the key player in the supply chain and production network both regionally and globally. In this time,

https://www.change.org, accessed on Monday, February 6th, 2017. 
we are welcoming the establishment of the AEC, a community that is not only emphasizes the establishment of a single market from purely economic terms, but also pay attention to the unification of socio-cultural aspects especially the readiness of human resource. It is important to develop human resource. It is also important to create the best strategies for sustainable development, poverty alleviation programs, cooperative education, and the empowerment of women and children in order to reduce the development gap which is still quite large among the member countries of ASEAN. Through the AEC, domestic entrepreneurs can have the capability to "Go International". Step-by-step, the strategies that must be done in accordance with what is recommended in the pillars of the AEC blueprint in 2015 which requires each ASEAN country shall be reformed all the elements that become essential and absolute requisite sector in order to face the implementation of the AEC. Economic globalization requires increasing competitiveness is strong in technology, management, human resources and continuous efforts in fostering innovation and creating cost efficiencies. So that, to compete in the preparation of a world without borders or borderless is by communicating with English language both written and spoken which can be used in economic, social, culture, education and political sectors.

\section{WHY ENGLISH LANGUAGE?}

According to Joseph Stiglitz (2004), there is no single country is able to avoid themselves from globalization. ${ }^{2}$ It means that to make a network in the era globalization is very important. The network should be integrated in all the aspect of life such as economic, culture, social, politic, education, etc. Consequently, every state inevitably will

\footnotetext{
2 Joseph E Stiglitz. 2002. Globalization And Its

Discontents. New York: W.W. Norton. Hal. 22
}

enter the vortex dynamics of the world, the dynamics of cultural, political, security included in the vortex of the global economy. In the context of economic globalization, the de facto ASEAN Economic region has a strategic value in promoting economic growth of Asia. It is because Asia has the largest area of the world is $30 \%$ of the total land of the world (approximately 44 million $\mathrm{km} 2$ ), and the largest population for about 4 billions people. From that facts, it can make ASEAN become the biggest labor supply in the world and become the tightest competition among skilled labors to get an opportunities in working in ASEAN regionally and internationally..

AEC will apply more labor competing seize employment opportunities among ASEAN countries, especially the local workforce in the country itself. Of course for workers who have a high labor competition, will have a greater opportunity to gain an economic advantage by the AEC. The quality of human resources should be improved both informally and formally and both in their country and among ASEAN countries to prevent the flood of skilled workers from abroad. This work is not easy because it must require their blueprint education system and certification of a wide range of professions. It can be realized, that education, especially higher education has an important role in supporting the establishment of AEC and to prepare the Indonesia citizen to deal with regional integration. Indonesian human resource is not fully prepared yet for the AEC, so that must be trained and strengthened through many skills. Due to the well-trained workforce is much more important than the well-educated workforce. The educated human resource without being accompanied by the sufficient competition can be defeated by a skilled and well trained workforce. 
Entering the era of globalization, or better known as the free market requires every person to prepare themselves with a reliable resource, especially in the field of communications. In this case the role of the English language are required both in mastering communication technology as well as interact directly. As a means of global communication, the English language must be actively controlled both oral and written. Relates to the importance of mastering a foreign language, Johann Wolfgang Von said that those who know nothing about foreign language, they know nothing about their own reviews. This saying implies the importance of foreign language education as the additional language beside the mother tongue and the national language. Therefore, in that context, the need for a paradigm of thinking about the importance of English, which is a new perception that in the era of globalization facing Asian Free Trade Area (AFTA), where the competitiveness of each individual of many countries competed with each other in dominating a wide range of employment or business. In addition, Indonesian language as a unifying language (national language) must be mastered. English language is the international language becomes a second language that also should and must be mastered. The reason is English as the global language. It was the instrumental device in the interaction, global communication and competition along with the progress of globalization. In short, understanding of English as a global language should not be associated with extinction or threat and disruption to native language or mother tongue unless it is an option.

More than that, the English language has become a keyword in capable of grasping all aspects, be it business, politics, social or cultural. In the past, maybe English is still a bit taboo thing to be studied and understood deeper because the people had not realize the advantage of acquiring English language especially in this globalization era. In this time on the contrary, the English language is the communication tool in the era of globalization. It is the main factor in achieving career success of a person with a brighter future. Given, in particular communication in languages internationally to bridge various activities. In other words, the ability to speak English can also be used as an investment. Like the plant, must wait to reap the results. The advantage of these investments are in the global market then we will win the competitiveness and be able to continue to survive with proficiency in English.

Paul Lewis (2009), which indicates that English puts ranked 3rd as the language most used in countries worldwide recorded a total of 172 languages. English is known that it have been used by more than 112 countries around the world including the countries of the ASEAN region and 328 million users of the language. From the survey results, it can be concluded that English is the language most widely used by the countries in the world. Although the number of English users more than the number of users in Spanish and Mandarin. It's the underlying reason why the citizens of Indonesia should be able to use English to face the AEC. Mastering the English language does not mean forgetting or discriminate against Indonesian, but in this case we have to make the English language as a medium to introduce Indonesian to ASEAN countries. This is the true role of the English language for the advancement of Indonesia.

In addition, of course, almost all the technology devices are operated in English. Moreover, if people want to work in a multinational company or a foreign company, automatically our English skills are very questionable, the main requirements, and the most important. Based on those reasons, it is possible the rapid technological development requires us to be more proactive in responding to 
global information flows as an asset in meeting the needs of the market.

As the world's lingua franca, English is not only as an academic requirement for its mastery. It is not only limited to the aspects of language knowledge but also as a global communications. To master English well, we should emphasize the learning process aspects of the exercise, so that the students will be actively involved in presenting their opinions or ideas freely according to the real conditions. It is highly recommended because the knowledge of the English language of Indonesian citizen becomes an inevitability. Like it or not, this subject had to be learned by everyone in Indonesia. Mastery of English is not only necessary for those who will go abroad, but mastery of the English language has become a national interest. For example, we had no difficulty when engaging in the business of global scale. The national businesses are not only required to run using the Indonesian language but also use English. It is logic because how people know our local product when we can not communicate our product to the people.

At present higher education institutions are encouraged to produce international quality graduations who are equipped with professional skills, language skills, and intercultural skills. Liberalization of trade in education services is an opportunity for higher education institutions to welcome foreign students, especially from ASEAN member countries. But basically the higher education institutions should improve the quality of faculty, curricula and facilities to meet international standards. In addition, higher education are also required to develop excellent skills in collaboration with the institutions or other parties as well as with the development of student activities unit. So, it is expected to create an educated human resources with the skills trained. By joining this, Indonesia, as a member of the $\mathrm{AEC}$, will be a lot of changes. Indonesia could become a big country and is able to become the winner or it could even be worse as the loser because of losing competitiveness with each other as the effect of the globalization area.

AEC only stayed a matter of months, meaning that the AEC has been present in the eyelid. Like it or not, ready or not, amid weakening Indonesian rupiah increasingly dying should still stands proudly to deal with it. The reason is the implementation of AEC. It is causing traffic free trade in the region have been without obstacles. Free trade means no tariffs and non-tariff barriers for the member countries of ASEAN. This condition must be a challenge for Indonesia from all fields, whether economic, political, educational and cultural. Therefore, to face AEC, Indonesia still has a variety of homework to be improved in order to remain this competitive condition.

For socio-cultural pillar, Indonesia still need to work hard since there are many Indonesian citizens who do not know about ASEAN. In one of the keys to success in AEC is the connectivity or contact between the Indonesian citizens and other ASEAN countries. Meanwhile, one of the most powerful media to establish connectivity with ASEAN countries is through a foreign language, namely English. Today many misguided toward mastery of English, students for example, they are chasing the English language only for pride or style but actually studying English is more important than to get the pride and style. Studying English has a big purpose to survive in their future because they will live in the globalization era more than today. This is a view that needs to be clarified, English teacher should be able to instill a paradigm that mastering English is not just for pride, get a cool title or other terms that do not lead to the actual function of language. Mastering English is as the communication tool for them to have a connectivity and contact with other people not only in ASEAN countries but also all over the 
world in all aspects of life such as economic, social, politic, education and culture.

In the context of linguistics, language is not only as a tool to communicate but also the main tool to open up the world. Through language, humans are able to obtain information without limits. With those information, person is able to understand the forms of every variety of human understanding. AEC 2015 is a door for ASEAN countries in entering Indonesia. As a logical consequence, there will be a lot of foreign workers going to attack Indonesia. Responding to this, of course, Indonesia should immediately prepare competent people in the field, not just the professionals who are responsible for welcoming AEC, but this applies to the whole society, and not only for the students.

In line with this, the President of Indonesia, Joko Widodo has signed Presidential Decree No. 69 Year 2015 on Visa Free Visits for foreign nationals from certain countries. This is done by the government to increase the number of tourists as well as increase the visa of the trip. The existence of these rules will automatically be more enliven AEC and certainly increase the number of foreign nationals visit to Indonesia. In this case the people of Indonesia should be able to take the opportunity to market local knowledge possessed Indonesia and, once again, English language become important as a medium of communication. Moreover, from now on the people of Indonesia should be able to master the local culture possessed by every individual areas. So with the mature insight into the culture and fluent in English would be very easy to market the wealth of culture and traditions of Indonesia to the students in particular. As an educated people must be able to prepare their ability in terms of insight into the local culture and hone their English skills. Thus it would be

3 M. Nazir. 2003. Metode Penelitian. Jakarta : Ghalia Indonesia. Cet.ke-5, hal. 27. very easy for academics to develop the tourism potential and local culture, especially to foreign tourists. However, mastery of English here is not just limited to the travel sector. It means that the Indonesian people not only can be a guide, through English, they are also able to master all areas, such as developing the creative economy and introduce Indonesian tourism and culture to other countries regionally and internationally.

\section{RESEARCH METHOD}

According to M. Nazir (2003), a literature study is a data collection technique by doing a review study of textbooks, literatures, notes, and reports which related to the topic that must be solved. ${ }^{3}$ According to Sarwono (2006), a literature study is a research method used data collecting technique by collecting information from books, magazines, newspaper, and other sources to build a basic theory. ${ }^{4}$

The literature study has two important steps. The first step is to decide the topics. After the researcher stated the topic, the next step is doing study related the research topic. In doing the study means that the researcher starts to collect the data. In collecting the data, researcher collects many information from related literatures. The data sources are taken from textbooks, journals, articles, research finding, internet articles, newspapers, magazines, etc. Those data are used by the researcher to compose the study systematically. So that, the literature study included the common process such as identify the theory systematically, literature finding, and document analysis related the research topic.

In this study, the topic is about the importance of English in facing AEC. So, the data sources are related to this topic. The data were taken from textbooks, journals,

\footnotetext{
${ }^{4}$ Sarwono Jonathan. 2006. Metode Penelitian Kuantitatif dan Kualitatif. Yogyakarta :Graha Ilmu
} 
articles, research finding, and internet articles. After the researcher collected the data, the researcher composed the research systematically. The objective of this study is that the result can develop the understanding of the students and workers about the importance English language both written and spoken in facing this AEC and prepare the readiness of the students and workers to compete with the others in ASEAN countries in taking an opportunity of working by acquiring English language both written and spoken.

\section{ROLE OF ENGLISH IN FACING AEC}

AEC is in front of all ASEAN counties and that is the fact. Like it or not, ready or not, the weakening Indonesian rupiah and increasingly dying should still stand and hasn't changed yet. The reason is the implementation of AEC 2015 causing traffic free trade in the region have been without obstacles. This condition must be a challenge in itself for Indonesia from all fields, whether economic, political, educational and cultural. For socio-cultural pillar, Indonesia still need to work hard since there are many Indonesian citizens who do not know about ASEAN. In one of the keys to success AEC is connectivity or contact between the citizens and the other ASEAN countries. Meanwhile, one of the most powerful media to establish connectivity with ASEAN countries is through a foreign language, namely English.

According to Paul Lewis (2009), which indicates that English puts ranked 3rd as the language most used in countries worldwide recorded a total of 172 languages. ${ }^{5}$ From the survey results it can be concluded that English is the language most widely used by the countries in the world. Mastering the English language does not mean forgetting or discriminate against
Indonesian, but it can make the English language as a medium to introduce Indonesian to ASEAN countries. This is the true role of the English language for the advancement of Indonesia.

There is a misguided in mastering the English. English language is the main tool of communication in getting a connection with other people across the boarder means internationally. But sometimes, mastering English is only for pride. It is not fully true and not fully wrong. Mastering English means that the people can communicate with other people internationally and also by mastering English, they can learn many aspect of life such as technology, education, economic, culture and politic. English is a tool to communicate about aspects of life. In this globalization era, people who cannot communicate with English will be a step backward from people who is mastering English. It means that the people who is mastering English will have modern thinking and they can learn many studies in order to get many innovation and many experiences.

\section{THE URGENCY OF ENGLISH LANGUAGE}

One issue that was widely circulated in the global economy is AEC. It is a form of integration of the countries in Southeast Asia in the economic field. In other words, will the emergence of a system of free trade in the region that allow goods, services and professionals from neighboring countries to enter Indonesia. This raises concerns for most people in Indonesia. Basically, the key to winning the competition in 2015, AEC does not lie in how much natural wealth in a country or a per capita income that is generated, but on human resources. Human resources into the most fundamental factor in winning the global competition in AEC 2015. It is not without reason. In global

\footnotetext{
${ }^{5}$ M. Paul Lewis (ed.). 2009. Ethnologue: Bahasa dunia . Edisi keenam belas Dallas: SIL internasionalhttp://archive.ethnologue.com/16/.
} 
economic competition, then products, services and professionals will easily fit into Indonesia, will indirectly lead to economic competition increasingly fierce. The chances of getting a job also will be smaller. The best graduates from all over Southeast Asia will enliven the labor market in Indonesia in 2015. Then it is possible to be a lot of educated unemployment that spread across Indonesia and the high poverty rate to high social inequality.

Entering the era of free-market AEC 2015 requires every individual to prepare a reliable resource, especially in the field of communications. In this case the role of the English language are required both in mastering the technology-based communications and in communicating directly. The need for a paradigm shift on the importance of English, which is a new perception that in the era of globalization in facing 2015, when the competitiveness of individuals from different countries compete with each other in dominating a wide range of employment / business, other than the Indonesian language as a unifying (national language) that must be mastered, the international language becomes a second language that should and must be mastered. The way to win a business is to mastering English for the communication. The way to introduce many superior products and explain the diversity of culture is also by mastering English as the communication This is a serious problem that must be resolved with the right solutions. To prepare competent and proficient human resources in English must be active and communicative on all elements of society which cannot be separated from the role of government that issued policies and training programs to improve society's ability to speak English. Readiness of human resources is a major factor in the era of free markets. In the era

\footnotetext{
${ }^{6}$ Sabita Sabina. 2013. Kesiapan Indonesia dalam
} Komunitas Ekonomi ASEAN 2015. of free market later, not only capital that can run across country borders. Many workers of the country would experience the same thing. Malaysia, the Philippines, Singapore, Thailand and other ASEAN countries become the main rival because of the language factor. So for the local workforce should be prepared with the ability to speak English are active.

The World Bank has recorded that there is a huge gap between the Indonesian skilled-worker quality and the worker from other South East Asia countries in facing AEC which had been started in 2015. One of the major problem is the English langauge skill. ${ }^{6}$ The usage of English is still minimize. It means that English is only learned but not practiced in daily life in the matters of spoken language. While except in South East Asia, English is mainly as the lingua franca and practically spoken everyday. Indonesia is the largest and the biggest countries in South East Asia, in this case, its archipelago, its tribes, its population, its natural resources, its culture, and its mother tongue. South East Asia countries see that Indonesia is the biggest market for their worker. It means that Indonesian worker must be prepared for this competition in finding job and keeping the job field are not fulfilled by workers from other countries. As Thailand government, they have opened the Indonesian language course massively in the whole country. The purpose is they want to send their worker and compete with the local worker from Indonesia itself. If it happens, the Indonesian worker must be ready to face this fact. The fact is Indonesian worker must have English langauge skill well, vocational skill improved, technological skill trained and eastern cultural habit kept. As this far, free market that have already done in Indonesia allows many products entering Indonesia, allows many

http://tsabitabee.blogspot.com, accessed on Tuesday 7th, 2017. 
other countries worker to get a job in Indonesia and many other countries in South East Asia plant their investation in infrastructure in Indonesia. This situation forces Indonesian government and Indonesian society must have a consideration that Indonesia is theirs, they cannot be loose with the worker, investation, and products from other countries. If Indonesian workers wants to conquer other countries and keeping their countries, they must conquer the language. If they cannot communicate with other South East Asia language, they can communicate with English as the international language. International means that English is spoken in many countries in the world. Everyone who works abroad or travel abroad are certainly communicate with English language first then its national language if it is necessary.

As the next generation of Indonesian society, the Indonesian students must be provided with the competence in speaking English to prepare them for twenty years later. It is the assignment for not only government but also the society of Indonesia to prepare their next generation well through English language education, vocational education, technological education and character education. Those integration education can make Indonesian society stronger in facing AEC today and in the next future. The development of Indonesian human resources can be built through many aspects especially in education. Through education, Indonesian government and society can be support each other to give the best curriculum for the students in the school. The curriculum should be presented many aspects of life such as social, economic, politic and culture. Beside those aspects of life, they must prepare the students with the skill in technology because in this globalization era, the students must study the technology as the device to communicate through many countries regionally and internationally. Once again, English is also important to be learned by the students because people always communicate and the communication should be in English as the international language. All the preparation, from education untill technology, are to prepare the Indonesian next generation become a competent, skilled, proffesional human resources in order to be ready to compete with the human resources from other ASEAN countries.

\section{CONCLUSION}

Mastery of English is one of the basic capital to be able to compete in the face of the globalization era, especially the ASEAN Community, which is AEC. As an ASEAN identity, English should be taught to the students as the future generation of primary education up to higher education. This is the assigment for the government to prepare their people to be ready in facing this globalization era. In this era is growing forward and open up opportunities to expand the scope of inter-state. Only people who have foreign language skills can take this golden opportunity. Foreign languages have an important role especially in the career. The world of work will give high appreciation to the people who have good English skills. Be able to join in multinational companies, foreign language of English is the main requirement. To complete their skill, they must also acquire the technology and vocational skill.

AEC is the time for academics and Indonesian people in improving their English skills both for communication purposes as well as for special needs in facing AEC and to bring Indonesia in the better direction and better condition. As the wise word, "If we want to conquer a country, we must conquer their language first". It means that language is the key of communication in communicating many aspect of life. In this case, in making connectifity and making a connection with other people in many countries not only regionally but also internationally in social, culture, economic, education, politic and many aspect of life. 


\section{REFERENCES}

Adam, I. 2012. Bahasa Indonesia vs Bahasa Asing. (bahasa.kompasiana.com/2012/09/2 0/bahasa-indonesia-vs-bahasaasing), accessed on Thursday 9th, 2017.

Handayani, Sri. Pentingnya Bahasa Inggris sebagai dalam Menyongsong ASEAN Community 2015. Pendidikan Bahasa Inggris Universitas Slamet Riyadi Surakarta. Jurnal Profesi Pendidik, Volume 3 Nomor 1, Mei 2016 Halaman 102-106.

Hidayat, Arifah. 2011. Peran dan Strategi Pendidikan Tinggi dalam menghadapi ASEAN Community 2015. Unihas Bengkulu.

http://dimastidano.wordpress.com/2012/11 /28/masyarakat-ekonomi-asean2015-peluang-atau-14ancaman/, accessed on Wednesday 8th, 2017.

http://edukasi.kompasa.com/read/2011/09/ 26/21320318/Kemampuan.Bahasa.I nggris.di.Indonesia.Rendah, accessed on Wednesday 8th, 2017.

http://suarajakarta.com/2012/10/14/kesiapa n-masyarakat-indonesia-menujumasyarakat-ekonomi-asean-2015/, accessed on Tuesday 7th, 2017.

http://archive.ethnologue.com/16/ Jonathan , Sarwono. 2006. Metode Penelitian Kuantitatif dan Kualitatif. Yogyakarta :Graha Ilmu

Lewis, M. Paul (ed.). 2009. Ethnologue: Bahasa dunia. Dallas: SIL internasional Edisi keenam belas.

Muliasari, Cut. 2013. Peran Pendidikan dalam Menghadapi AEC 2015. http://regional.kompasiana.com/201 3/12/14, accessed on Monday February 6th, 2017.
Nazir, M. 2002. Metodologi Penelitian. Jakarta : Ghalia Indonesia.

Rashor, Syafrina Fauziah. 2013. Bahasa Asing Penunjang Keberhasilan AEC 2015. Jakarta. https://www.change.org, accessed on Monday, February 6th, 2017.

Rore, S.L. 2012. Pentingnya Bahasa Inggris dalam Era Global, (manado.tribunnews.com/2012/06/ 25/pentingnya-berbahasa-inggrisdi-era-globalisasi), accessed on Friday 10th, 2017.

Sabina, Sabita. 2013. Kesiapan Indonesia dalam Komunitas Ekonomi ASEAN 2015. http://tsabitabee.blogspot.com, accessed on Tuesday 7th, 2017.

Stiglitz, Joseph E.. Globalization And Its Discontents. New York: W.W. Norton, 2002. 